\title{
Thought Of Socialism According H.O.S.Cokroaminoto
}

\author{
Firdaus Syam \\ Postgraduate Program of Political Science, Universitas Nasional \\ Ali Syaefa \\ Postgraduate Program of Political Science, Universitas Nasional \\ Syaef_welehweleh@yahoo.com
}

\begin{abstract}
:
This paper is entitled Thought of Socialism According to H.O.S Cokroaminoto. Authorinterested in researching and elaborating on his thoughts. Due to the idea of socialismthis appeared in the early era of national awakening. In doing researchThe author uses a qualitative method by analyzing secondary data ISSfrom several books, journals, and existing writings. From the results of these studiesit is known that socialism is a collection of ideas and ideas withinorganize society based on the principle of prioritizing intereststogether in an effort to realize justice and prosperity that is more equitable.H.O.S Cokroaminoto found the compatibility of essence or substancesocialism with moral values in Islamic teachings. According to him there are 2 (two) waysso that the teachings of socialism can be realized. First, by cultivatingawareness of the value of socialism in thoughts and actions in society.Second, by creating a government (gouvernemeny that socialistl).
\end{abstract}

\section{INTRODUCTION}

The political thinking of Indonesian national figures has always been interesting studied and scrutinized by the next generation. By studying and observingideas, ideas, and thoughts from Indonesian national figures can be used as materialreflective in participating in the development of the Indonesian Nation. Aside from that,the benefits obtained as a reference in viewing an eventpresent that is happening.

The author is interested in discussing the political thoughts of the early awakening figuresnational. That is a time when the spirit of national awakening was marked in the earlyearly 1900s. The spirit of national awakening is marked by its existencethe collective spirit of fellow children of the nation in rejecting and opposingcolonialism and colonialism carried out by the Dutch. Spiritcollectivism is also characterized by a common spirit to establish an association 
The writer thinks that the idea was born from the resurrection figurenational is an interesting idea because it was born in a full atmospherepressure. In addition, it can also be said that political thoughts are born from figuresnational awakening is a thought that determines the direction of thoughtnational politics in the future. Maybe, maybe without political ideaswhich was started by national awakening figures, to date the NationIndonesia has not yet experienced independence.One of thenational awakening figures is H.O.S. Cokroaminoto.national awakening figures from among the Muslims. Islam itself isthe majority religion adhered to by the Indonesian people. Cokroaminoto is famousbecause of his intelligence and boldness in conveying ideasthe idea. Especially when he chaired the Sarikat Islam (SI) organization. Aside from that,Cokroaminoto was respected by the people and government of the Netherlands Indies because of himis a descendant of a noble family and well-known scholars in the residency Madiun-Ponorogo in East Java. Because he came from the Javanese priyayi elite, then he got the opportunity to receive formal educationorganized by the Dutch East Indies government. The chance he had he didn'twaste it and study diligently so that he is able to finish education well

In writing this paper the writer wants to explore and exploreCokroaminoto's ideas or thoughts by asking a question as

following;

1. What is meant by and how did the development of Sosialime begin?

2. How is the concept of socialism promoted by H.0.S Cokroaminoto?

In preparing this paper, the author uses qualitative methodsby conducting an in-depth analysis of some of the available data sources.Then it is described carefully in order to stay awakeaccuracy. The existing data, the author obtained through literature study. Good ofscientific books as well as from nationally recognized journals.

To facilitate and avoid confusion regarding certain themeswill be discussed in the paper, where the theme title is "ThoughtSocialism According to H.O.S Cokroaminoto. ", The authors made severaloperational definition as follows:

1. Thought is a set of ideas or ideas that come fromfrom someone and recognized by the surrounding community. 
2. Socialism is a willful collectivitycommunity welfare through community regulation throughpeople's government.

With the operational definition above, it is hoped that the author canconsistent in conducting the discussion. Apart from that, the operational definition is in ordercan make it easier for the readers of this paper to grasp what really isreferred to by the author.

\section{DISCUSSION}

\section{Socialism: Early Development}

The word socialism is a foreign word that does not come from a vocabulary Indonesian nation. Socialism originates and develops in European countries. Socialismitself means a collective notion that was born among the people asform of protest against the adoption of a capitalist system that does not bring prosperitythat is evenly distributed among the people (Ebenstein, 1961: 167).

According to Danziger in Wijiyanto and Sudrajat it is said that Inthe tradition of political thought, socialism develops because of inequality,poverty, and the exploitation of individuals in the 19th century. Somethingphenomena that actually occur simultaneously with the emergence and developmentindustrialization and democracy. Socialism, therefore, develops asdiology that focuses on the suffering of individual groupswith relatively small economic, social and political powers (WiIlyanto andSudrajat, 2019: 1). If so, then it can be concluded that socialism was bornmotivated by the fact that the concept of social, economic development,and politics based on the capitalist system is considered to fail to deliverprosperity.

According to Bottomore in Winaryo, socialism is oneterminology in social science thinking is not something that is haram. Termit was first introduced by Saint-Simont in France approx.

The 1830s. This thinking is an intellectual response to social conditionsand the new economy that was created in connection with the emergence of capitalism inindustrial sector. Socialism is a string of ideas (stands of thought)take effect. Hence, his progressive ideas about development wereassociated with the consciousness and rational regulation of human social life a lotcited in sociological theories (Winaryo, 2000: 1). 
In its initial idea, socialism was a concept of togethernesswhich is the anti-thesis of the nature of individualism. Because only with passiontogetherness of prosperity can be felt. One of those figuresdeveloping the idea of socialism is Karl Marx. Where it states thatsocialist is one of the phases towards a communist society, afterthis society passed through the feudal and bourgeois stages. ever since Max statedthe idea, socialism in Europe is understood more as a political movement thanas an economic movement. Those who make communism a movementforbidden then automatically prohibits the ideas of socialism. Because ifsociety actually develops as linearly as one thinks

By Marx, socialism will be a stage towards communism, automaticallymust also be stretchy. and socialism and its derivations and variants.Through Marx's ideas, the effort to realize the ideas of socialism must be realizedthrough formal political efforts. This effort is to control the branchespower in a country. This in turn activates the peopleand the workers to seize power in the country by means ofseize, revolution. So that often the followers of socialism who adopt itand using Marx's ideas as a very aspiring founding referencea communist country. In his efforts to seize state power ofteninvolved in rebellions, whether large or small.

Finally, in the early 1900s, the idea of socialism andCommunism spread rapidly from Europe to countries in Asiawhat is generally being colonized by European countries that are the placethe birth of socialism itself. The idea of the need for resistance toan elite group that would never care about the fate of commoners(proletariat) is well received among people in Asian countries. Notis the exception, in Indonesia. The idea of socialism was well received by some movement figures in Indonesia in the face of colonialismcarried out by the Dutch East Indies Colonial. Among the figures of movement are quiteit seems that they have ideas of socialism are H.O.S Cokroaminoto and Tan Malaka.However, H.O.S Cokroaminoto has its own uniqueness insideelaborating on the meaning of socialism. The ideas of socialism that he conveyed were morerelies on the values of the Islamic religion as practiced byProphet Muhammad SAW at the beginning of the 6th (six) century AD. The idea is notmany refer to the concept of European Socialism, even though Karl Marx.

\section{Socialism According to H.O.S Cokroaminoto}

H.O.S Cokroaminoto lived in the Dutch colonial era. He could feel ithow the Indonesian society suffered under colonialismNetherlands. The life of society is miserable and oppressed. Very far fromfair and prosperous treatment. Therefore, so that people can getjustice, prosperity and prosperity. So, it must be fought for. Laview that only by practicing the 
teachings of socialism properlyand perfect, justice and prosperity for the people of Indonesia canachieved.

However, according to him, it is not necessarily the adoption of socialismsourced from Europe alone. However, SoSialism comes from valuesIslamic teachings that became his inspiration (Manan, 2016: 5). Despite the similaritiesbetween Western Socialism and Islamic Socialism. Namely, in terms of enthusiasmequality wants to protect society and make society prosperous. However,there is still a difference. Because Western socialism is closely related toCommunism. Where Communism in its views contradictsvalues that are rooted in Indonesian society who believe inGod. This is certainly not in line with the values of the Indonesian people. Thus, H.O.SCokroaminoto emphasized that the best and undoubtedly for the communityIndonesia is Islamic Socialism. A concept of brotherhood wrapped byreligious values.

If you pay close attention it can be seen that there are 2 (two) waysso that the notion of socialism can bring real good to society.First, understanding the meaning of socialism and its practice in everyday life.day by all members of society from all walks of life. Second, establishinggovernment (gouvernement) which is based on the teachings of socialism.

According to him, first, the meaning of socialism is "Socius". Originatedfrom Latin meaning friend. In Dutch it means"Maker" and in Arabic means "Asyrat". Both mean friends in Malay (Cokroaminoto, 2018: 17). So, Understanding Socialismoriented to establish a political system based on the principle of brotherhoodor friendship. In its early development, Socialism in the West was born asanti-thesis of the practice of individualism and feudalism. Likewise the idea of socialismIslam was initiated by H.O.S Cokroaminoto in the early 19th century in thebackground backslide by his disapproval of the practice of colonialism by colonialism. Lawitnessed firsthand that the indigenous people or bumiputera were colonized andtreated unfairly by the Government of the Netherlands Indies.

H.O.S Cokroaminoto explained that there was a lot in teachingIslam which emphasizes the importance of brotherhood and avoids natureindividualistic. This is in line with the social law in society that is unitycan only be realized when there is collectivity. He quoted one of the verses of Al-The Quran which reads "Kaanan Nasu Ummatan Wahidatan". The meaning of the verse is"Indeed, all human beings are brothers / sisters / united". That is itlessons from the holy Quran on which socialism is based. If allmankind we make as one unity. It cannot be, the state 
mustobliged to strive to bring safety and happiness to all of them.It is a country like that that H.O.S Cokroaminoto initiated and realized.

To strengthen his idea, H.O.S Cokroaminoto tried to explainby elaborating on the root words of Islam itself. He wanted to show thatIslamic teachings really want its people to be peaceful andsafety. The word "Islam" has four roots in Arabic. First,Islam comes from the word Aslama. The literal meaning is submissive or obedient. Certainly submissive and obedient to Allah, His Messenger, and the appointed leadersby Muslims. Second, the word "Islam" comes from the root word Salima. MeaningLiterally safe. This means that Islam is a religion that desiresits adherents get happiness and security. Not just in the world,but get security in the hereafter. Third, the word "Islam" is rootedin Salimi's words. The literal meaning is pillar or harmony. Strictly speaking peoplepracticing Islam must be harmonious and united. Fourth, the word Islam "comes from the rootsaid Sulami which means ladder. If people lsla earnestlypractice his religion. So, the point is, they will not reach that degreeheight. The highest degree in Islam is the degree of piety. Thus,H.O.S Cokroaminoto tries to elaborate on the meaning of Islam.

In addition to what has been described above about the teachings of Islamshows about brotherhood or socialism. The practice of Socialismin Islam is also reflected in the behavior of the prophet who exemplifies in his lifewill be the importance of helping and protecting vulnerable groups. Nabi Muhammad SAW showed the practice of generous life to the groupweak society. Like orphans and the poor. Even the Prophet was angryonce when seeing an orphan being treated rudely or reprimanded. Whyso, because in the teachings of Islam is not known the existence of ownershipabsolute in matters of property ownership. Because, Islam teaches there are people's rightsothers in the property we own. Therefore, in Islam, generosity is taughtthrough zakat, infak, and alms. All three are very glorious worship.

The second thing that can be done in an effort to realize the values andthe teaching of socialism is to form a socialist government.Socialist rule here refers to how Islamic rule in the time of the ProphetMuhammad SAW in Medina and was continued by the four Caliphs. Especiall the time of Caliph Umar bin Khatab can be used as a guide. Socialist governmentit means giving a small group of competent peopleto govern the country is much better than giving power tomany people, yet incompetent and trustworthy.

Socialist government is not a model government (monarchy). According to him, the kingdom model has many weaknesses. Weaknessamong others, they see themselves as God's 
representative, so they seepower is his. So that in practice the royal governmentoften oppressive society and common people. In addition, a change of thronethrough inheritance it is often detrimental to society because of society at allnot involved and often does not result in good leadership.

He gave an example that at the time of Sahabat Ali ibn Abi Talib (the fourth caliphin Islam) lying in bed before death. People askhim promoted his son to replace him as caliph afterdied. However he rejected it, because he realized that it was the caseis not his right. But it is the right of the people. (Cokroaminoto, 2018: 156)

Cokroaminoto strongly emphasizes the need for good morality to beowned by state officials. According to him, a government (state) filled withpeople who are uncivilized, have no virtue in their hearts, nostrong and holy ground. Instead, it was filled with lust and evil desiresboth from the rich and the poor. Thus, such a country is notcould be the perfect country. Although the government is regulatedsocialistic. (Cokroaminoto, 2018: 142). If so conveyed byCokroaminoto. So, it can be concluded that the factor of morality of the organizerthe state is crucial in the achievement of the goals of the teachings of socialism.

Unfortunately, in reviewing the basic government establishment Islamic socialism. Cokroaminoto did not explain in detail. He is moreconvey Islamic moral values that must be used as guidance. So, deepCokroaminoto's thoughts of Islamic socialism are not very visiblethe establishment of a systematic government system

\section{CONCLUSION}

Based on the research results above, conclusions can be drawn as inbelow. First, what is meant by the teachings of socialism is a collection of ideas andideas in organizing society based on principlesprioritizing common interests in efforts to achieve justice andmore equitable prosperity. Besides the teachings of socialism were first discovereddeveloped in European countries as a form of protest against the systempolitical economy that relies on the interests of certain groups or ownerscapital (capitalism).

Second, the idea of socialism slowly spread and developed to the country Asian countries including Indonesia before Indonesian Independence One of the figureswho develop and disseminate ideas and ideas is H.O.SCokroaminoto. However, there are differences between ideas Socialism that came from Europe with the idea of socialism being conveyedby H.0.S Cokroaminoto. The teachings of socialism conveyed by Cokroaminotostands and relies 
on religious values, namely the religion of Islam which he adheres to. Lafind in many Islamic teachings the command to be socialist andnot concerned only with personal gain.

According to him, it is also possible to create a socialist life ordertaken in 2 (two) ways negligently. First, it must develop a moral attitudewhich must be practiced by society in all circles so that they always think andact for the common good and avoid individualistic traits because it is not in line with Islamic teachings. Second, forming a governmentsocialist. Unfortunately H.O.S Cokoaminoto did not review and explainin detail how the socialist government system. However, if seenfrom its spirit, it can be seen that a socialist government is a governmentwhich is run by a competent and trustworthy group of people.

\section{REFERENCES}

Ebenstein, William. 1961. Today's Isms. Jakarta: Publisher Swada.

Manan, Firman. 2016. Islamic Socialism: Political Thought Perspectiv H.O.S. Tcokroaminoto. Bandung: Scientific Journal of the Department of Political Sciences, FISIP Padjadjaran University.

Sham, Firdaus. 2009. Building Indonesian Civilization. Jakarta: Gema Insani.

Tjokroaminoto, H.O.S. 2018. Islam and Socialism. Bandung: Sega Arsy

Winaryo, Wahyudi. 2000. Questioning Socialism in Indonesia. Malang: Journal Bestari University of Muhammadiyah Malang.

Wijiyanto, Septian Teguh and Ajat Sudrajat. 2019. Tjokroaminoto: Islamic socialism.

Yogyakarta: Journal of Yogyakarta State University. 